\title{
KELAYAKAN TEKNOLOGI ELECTRONIC NOSE UNTUK MENDETEKSI URIN YANG MENGANDUNG METADON DENGAN MENGGUNAKAN PRINCIPAL COMPONENT ANALYSIS (PCA)
}

\author{
Nini Firmawati ${ }^{1)}$, Kuwat Triyana ${ }^{2)}$ \\ 1) Jurusan Fisika FMIPA Universitas Andalas Padang, Kampus Unand Limau \\ Manis Padang 25163, \\ 2)Jurusan Fisika FMIPA Universitas Gadjah Mada,Sekip Utara Yogyakarta 55281 \\ Email: firmawatinini@gmail.com
}

\begin{abstract}
ABSTRAK
Telah dilakukan penelitian untuk menguji kelayakan teknologi electronic nose pada sampel urin yang mengandung metadon dengan urin yang tidak mengandung metadon dan air murni sebagai referensi. Sistem pengenalan pola yang digunakan adalah Principal Component Analysis (PCA). Berdasarkan penelitian yang dilakukan itu diperoleh bahwa hasil plot PCA menunjukkan adanya kecenderungan sampel yang sejenis mengelompok sesuai jenisnya. Kemampuan PCA dalam mengelompokkan data dari hasil luaran sensor gas tersebut menunjukkan bahwa electronic nose yang digunakan memiliki performa repeatibility yang baik dan layak digunakan sebagai alat pendeteksi urin yang mengandung metadon.
\end{abstract}

Kata kunci: electronic nose, principal component analysis, metadon.

\section{PENDAHULUAN}

Hidung manusia dapat sangat terlatih sebagai alat analisis untuk mendeteksi dan mendiskriminasikan bau makanan (misalnya ikan, daging, keju, dll) dan parfum (misalnya dalam kosmetik dan perlengkapan mandi). Namun, mungkin terdapat masalah kesehatan dan keamanan, dan juga mengenai variabilitas antar pengamat dan sensitivitas dari waktu ke waktu. Untuk mengatasi kesulitan-kesulitan itu, larik sensor telah digunakan untuk pengembangan teknologi electronic nose yang dapat meniru penciuman manusia, berdasarkan bahan volatil yang menghasilkan pola. Saat ini defenisi electronic nose diusulkan oleh Gardner dan Bartlett pada tahun 1994 adalah alat yang terdiri dari berbagai sensor kimia elektronik dengan sensitivitas parsial dan sistem pengenalan pola yang tepat, mampu mengenali bau sederhana maupun kompleks (Charaklias dkk, 2010).

Gambar 1.1 merupakan analogi sistem penciuman electronic nose terhadap sistem penciuman manusia. 


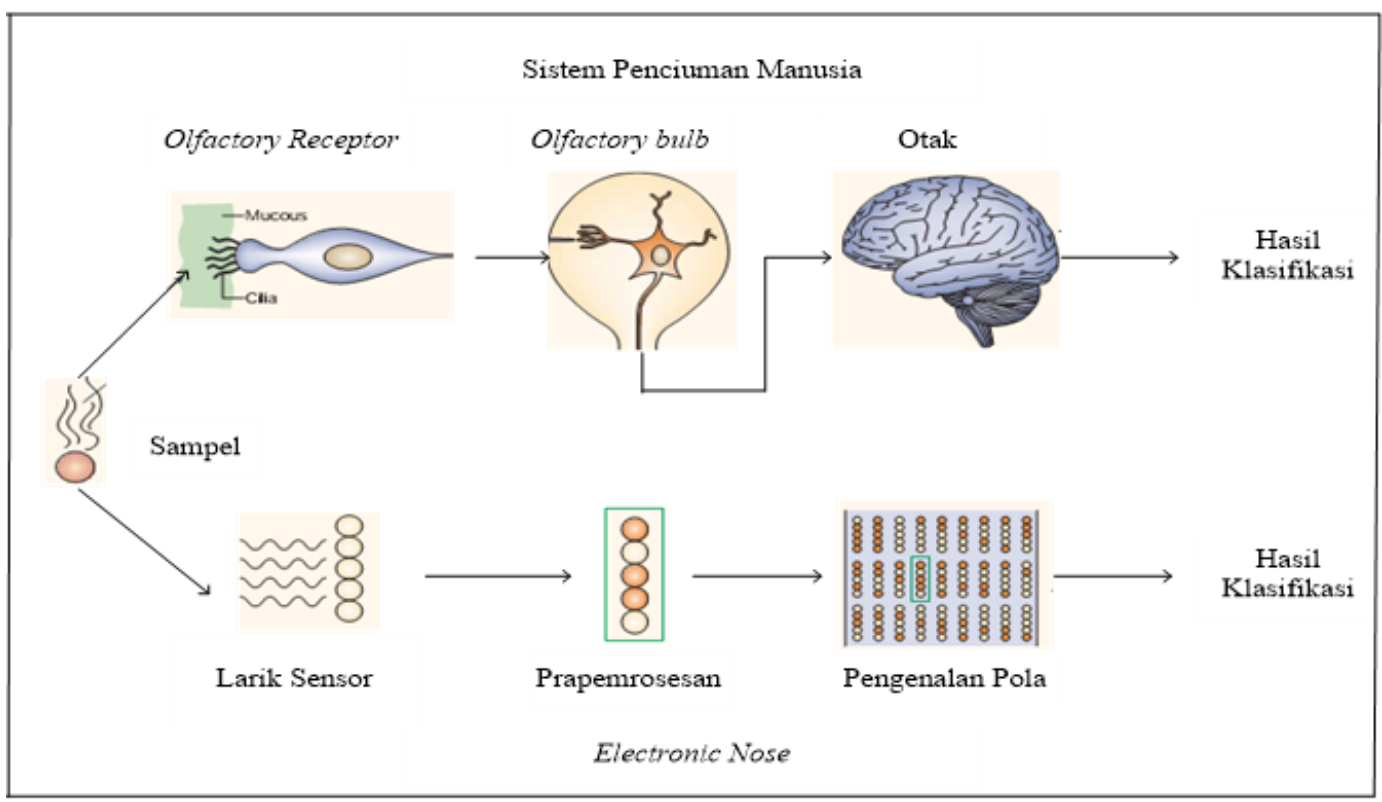

Gambar 1.1 Analogi sistem penciuman electronic nose terhadap sistem penciuman manusia (Turner dan Magan, 2004).

Electronic nose (e-nose) memiliki tiga bagian utama yaitu penanganan sampel, sistem deteksi dan sistem pengolahan data (Peris dan Gilabert, 2009). Diagram blok E-nose ditunjukkan pada Gambar 1.2 di bawah ini.

\section{Larik Sensor}

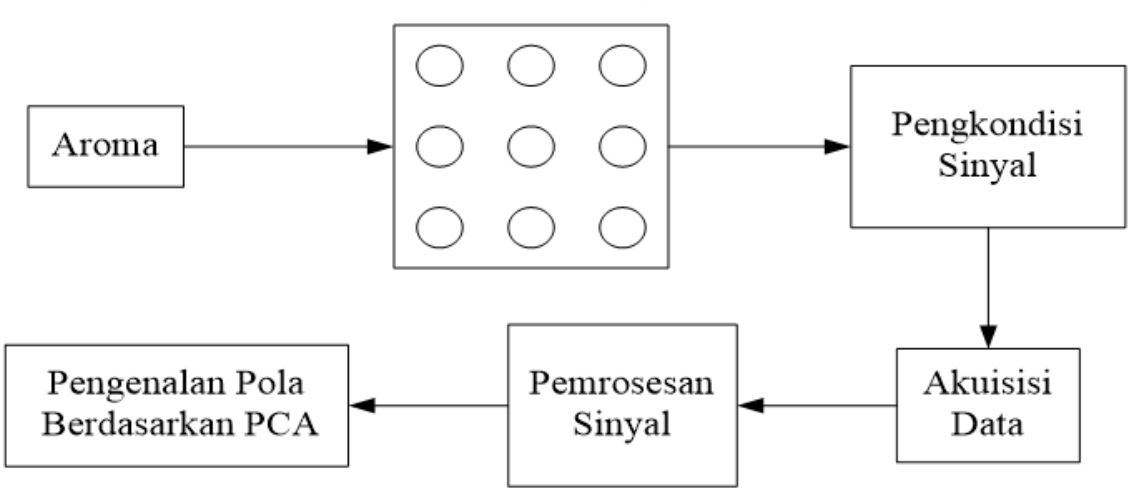

Gambar 1.2 Diagram blok electronic nose (Tan dan Halim, 2012)

Electronic Nose ini telah banyak diterapkan misalnya untuk mengidentifikasi kanker kandungan kemih (Bernabei dkk, 2008), untuk membedakan pasien yang mengalami penyakit Sarkoidosis yang tidak diobati, diobati dan dalam kontrol sehat dengan mengukur sampel pernafasannya (Dragonieri dkk, 2013) dan telah menerapkan electronic nose untuk membedakan nafas pasien Mesothelioma Pleura ganas (MPM) (Dragonieri dkk, 2012).

Peda penelitian ini, Electronic Nose diterapkan untuk pengujian urin yang mengandung metadon dengan membandingkan dengan urin yang tidak mengandung metadon serta air murni (aquades). Sensor yang digunakan adalah TGS 813, TGS 822, TGS 825, TGS 826, TGS 2620 dan TGS 2611. 


\section{BAHAN DAN METODE PENELITIAN}

\section{a. Bahan Penelitian}

Bahan yang digunakan pada penelitian ini adalah urin yang mengandung metadon, yang diperoleh dari dua orang relawan pada Program Terapi Rumatan Metadon (PTRM) di Puskesmas Gedongtengen Yogyakarta. Urin yang tidak mengandung metadon diperoleh dari dua orang relawan yang dikontrol makanannya setiap harinya selama tiga hari berturut-turut serta air murni (aquades) sebagai referensi.

\section{b. Tahapan Penelitian}

Pada penelitian ini ada beberapa langkah pengerjaan, diagram alir kerja penelitian dapat dilihat pada Gambar 2.1dan penjelasannya sebagai berikut:

1. Preparasi sampel, masing-masing sampel diukur dengan volume yaitu $2 \pm 0,05 \mathrm{ml}$ menggunakan gelas ukur. Setelah diukur, masing-masing sampel tersebut dimasukkan kedalam wadah yang terbuat dari aluminium foil. Wadah dibuat dengan panjang $4 \mathrm{~cm}$, lebar $4 \mathrm{~cm}$ dan tinggi $1 \mathrm{~cm}$. Setiap kali pengukuran, wadah sampel diganti dengan yang baru agar tidak ada sisa bahan pada wadah yang digunakan sebelumnya. Tidak ada tambahan senyawa lain dalam sampel.

2. Pengambilan data, ada beberapa tahap yang dilakukan yaitu:

a. Mencari nilai baseline awal sistem.

Untuk mencapai suhu kerja sensor dan titik stabil luaran sensor terlebih dahulu electronic nose dinyalakan selama 20 menit. Setelah itu, perekaman data dilakukan ketika sensor hanya terpapar udara bebas. Respon luaran sensor terhadap udara bebas digunakan sebagai data baseline.

b. Pengujian sampel

Setelah pengambilan data baseline dilakukan, sampel yang sudah dimasukkan ke dalam wadah yang terbuat dari aluminium foil diletakkan ke dalam ruang sampel. Pada penelitian ini proses sensing diatur selama 1 menit dan proses flushing diatur selama 2 menit.

c. Pemulihan respon sensor

Setelah pengambilan data dilakukan, ruang sampel kemudian dibersihkan. Setelah itu dilakukan proses flushing selama 10 menit. Hal ini dimaksudkan untuk membersihkan larik sensor dari aroma sampel sebelumnya.

3. Pengolahan data respon luaran sensor yang dihasilkan pada langkah dua menggunakan PCA. Hal ini bertujuan untuk mengetahui apakah Electronic Nose dapat mengklasifikasikan secara baik urin yang mengandung metadon dengan yang tidak. 


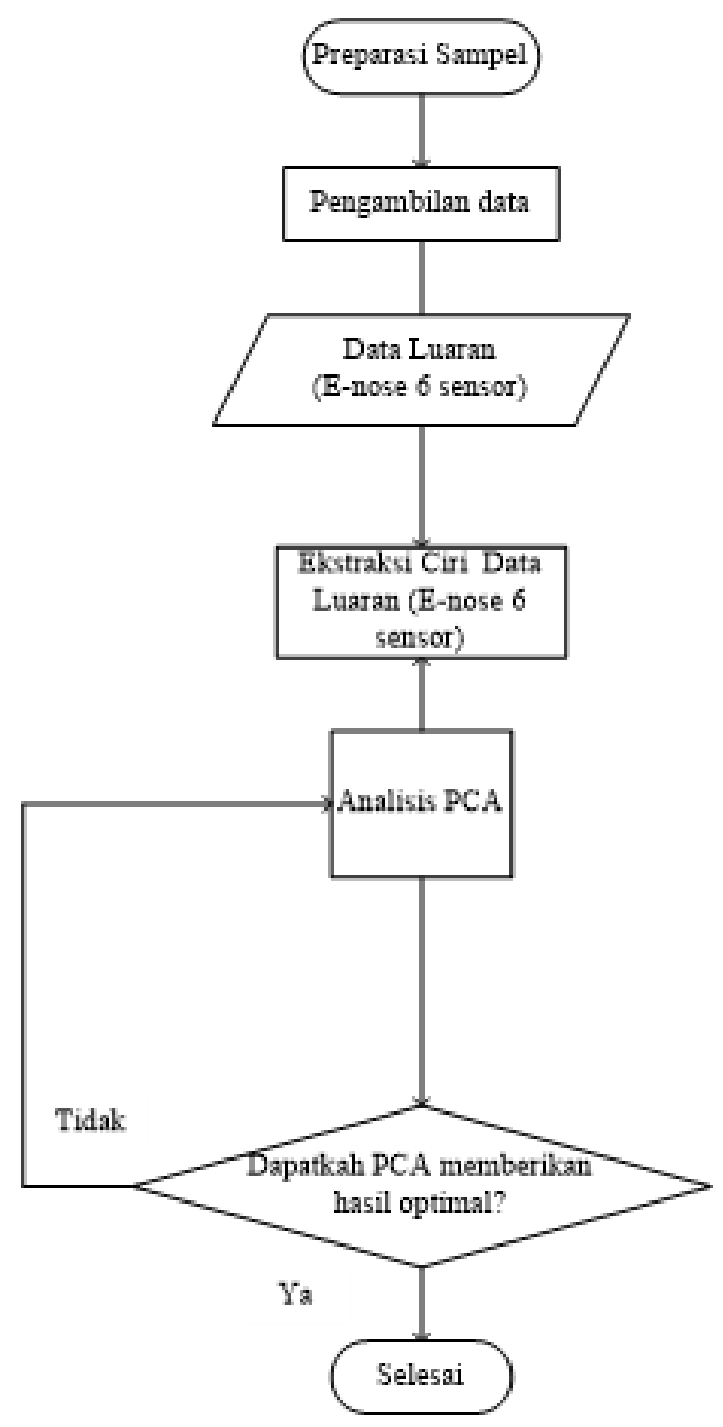

Gambar 2.1 Diagram Alir Penelitian

\section{HASIL DAN PEMBAHASAN} Respon Luaran Electronic Nose

Respon sensor electronic nose terhadap bau secara umum dianggap sebagai respon perintah pertama kalinya. Tahap pertama dalam analisis bau adalah mengalirkan udara bebas melalui sensor untuk mendapatkan baseline. Jika sensor terkena bau akan menyebabkan perubahan dalam sinyal output sampai sensor mencapai keadaan steady (Arshak dkk, 2004) sebagaimana ditunjukkan pada Gambar 3.1. 


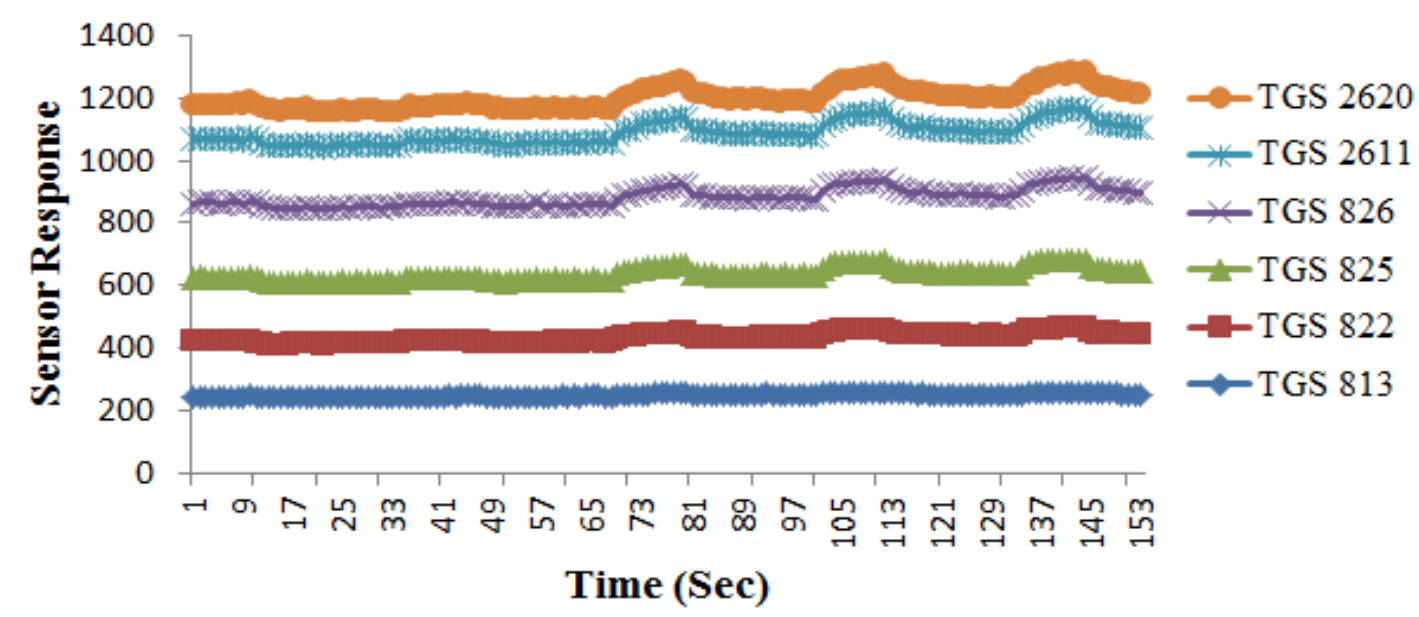

Gambar 3.1 Respon luaran sensor untuk sampel urin mengandung metadon

Respon luaran semua sensornya menghasilkan sinyal yang lebih tinggi dibandingkan sampel lainnya, namun belum didapat informasi sejauh mana electronic nose dapat membedakan sampel. Oleh karena itu dibutuhkan sistem pengenalan pola yang dapat membedakan sampel dan memvisualisasikan hasil analisis sehingga lebih mudah diinterpretasikan (Tian dkk, 2012). Pada penelitian ini digunakan metode principal component

analysis (PCA)

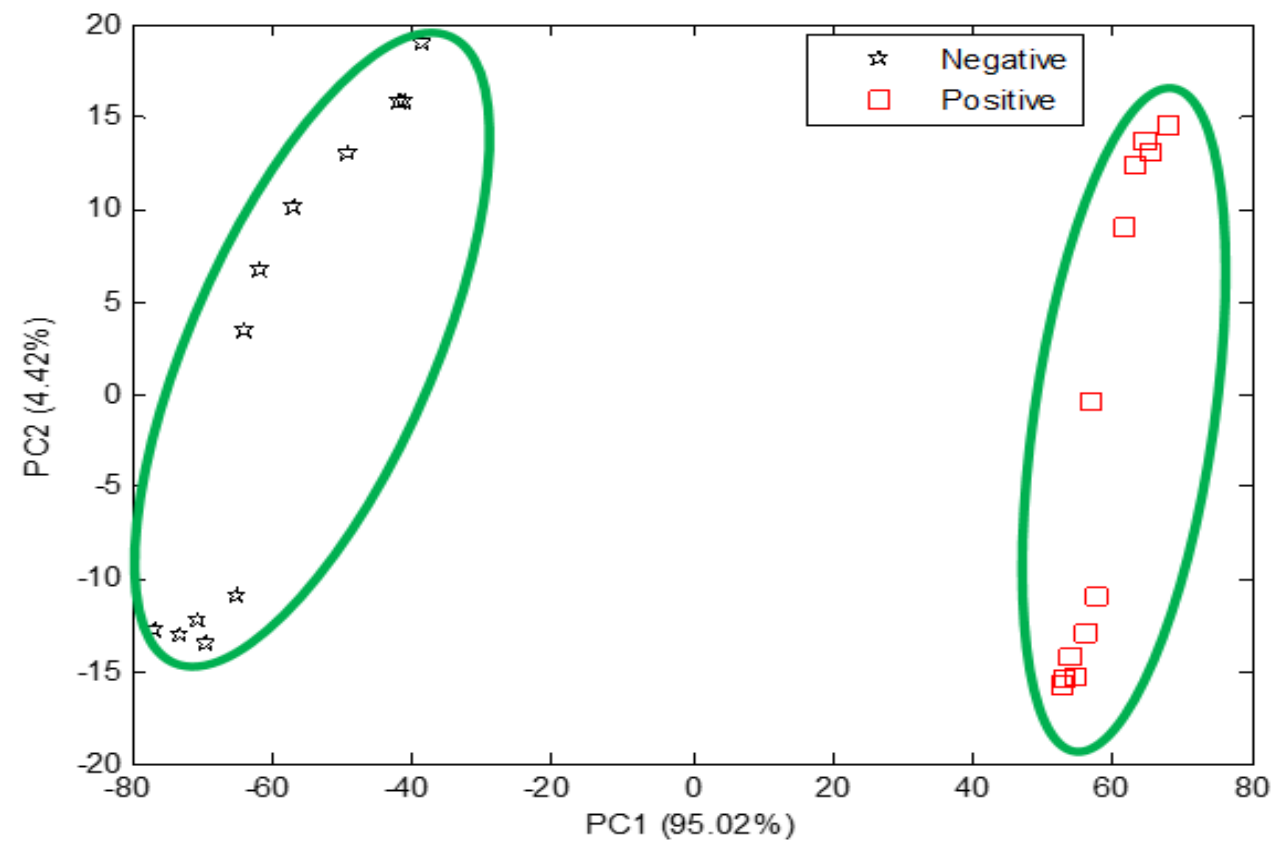

Gambar 3.2 Hasil principal component analysis (PCA) untuk sampel urin mengandung metadon dan yang tidak mengandung metadon.

Gambar 3.2 merupakan hasil dari pengenalan pola menggunakan Principal Component Analysis (PCA), dari gambar tersebut menunjukkan bahwa negatif artinya sampel itu adalah urin yang tidak mengandung metadon dan positif adalah urin yang mengandung metadon. Berdasarkan hasil tersebut dapat dilihat bahwa nilai persen variansi dari $\mathrm{PC}_{1}$ 
(95,02\%) dan $\mathrm{PC}_{2}(4,42 \%)$, sehingga total nilai variansi mencapai 99,44\%. Menurut Model statistik, sebuah diskriminasi dikatakan berhasil apabila mempunyai indeks antara 80 sampai 100 (Zhang dkk, 2012). Besarnya variansi data yang dimuat pada $\mathrm{PC}_{1}$ menunjukkan bahwa larik sensor yang digunakan saling berkolerasi dengan baik (Jun dkk, 2007).

Pada penelitian ini juga diperlihatkan hasil plotting PCA untuk seluruh data hasil pengujian. Dapat dilihat pada gambar 3.3, hasilnya menunjukkan bahwa dari tiga kali pengambilan data pengukuran terhadap sampel yang sama, setiap data memiliki kecenderungan untuk mengelompok berdasarkan jenis sampelnya. Kemampuan PCA dalam mengelompokkan data berdasarkan nilai input dari nilai respon luaran sensor gas dapat menunjukkan electronic nose memiliki performa repeatibility yang baik.

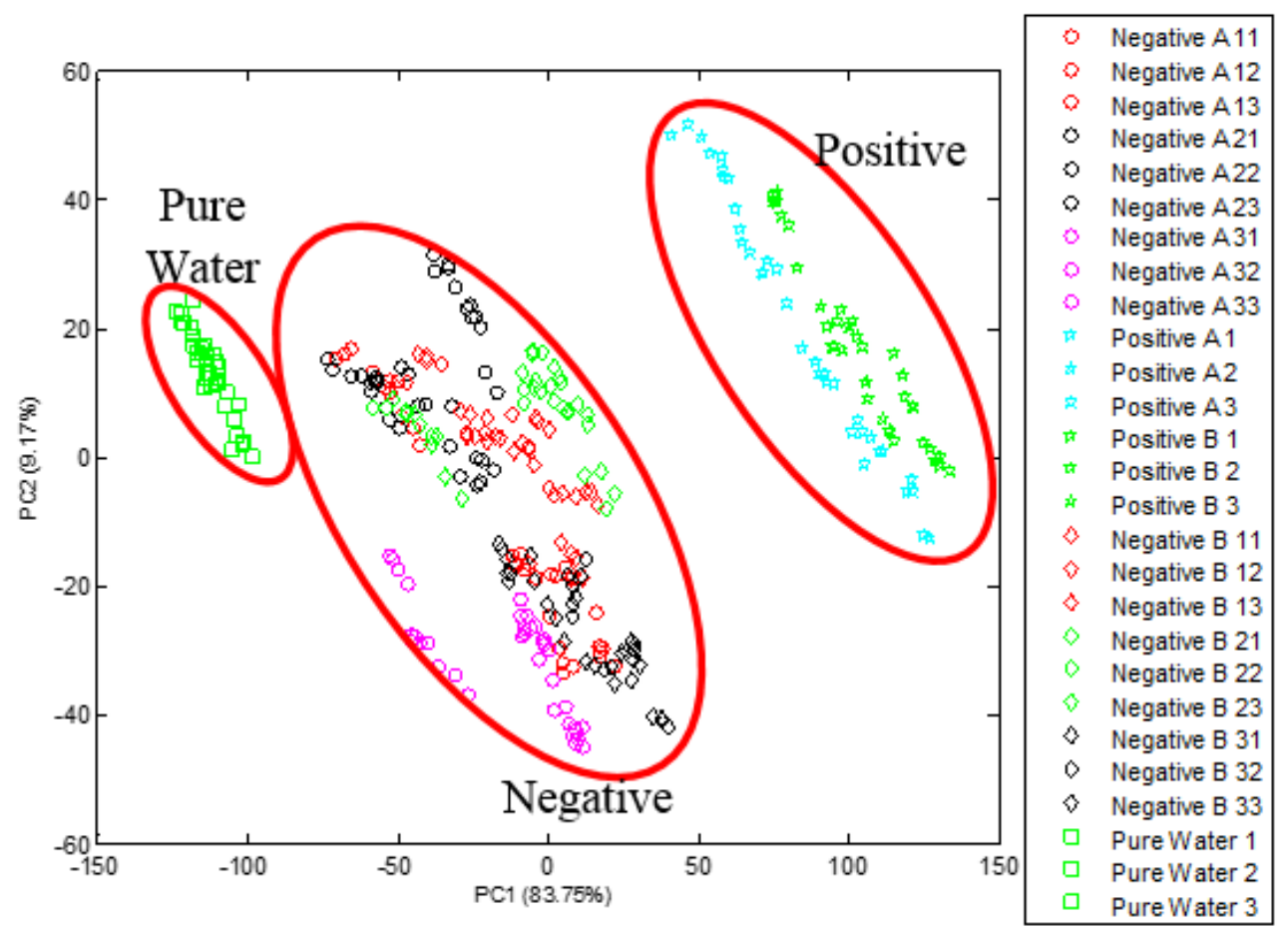

Gambar 3.3 Hasil analisis PCA untuk seluruh hasil pengujian

\section{KESIMPULAN}

Berdasarkan hasil penelitian yang dilakukan pada metadon dengan konsentrasi $10 \mathrm{mg} / \mathrm{ml}$ menunjukkan bahwa, hasil plotting PCA untuk seluruh hasil pengujian electronic nose memiliki kecendrungan untuk mengelompok berdasarkan jenis sampelnya. Kemampuan PCA dalam mengelompokkan data dari hasil luaran sensor gas menunjukkan bahwa electronic nose yang digunakan memiliki performa repeatibility yang baik.

\section{DAFTAR PUSTAKA}

1. Arshak, K., Moore, E., Lyons, G.M. and Clifford, S., 2004, A Review of Gas Sensors Employed in Electronic Nose Application, Emeral Group Publishing Limited. ISSN 0260-2288. 
2. Bernabei, M., Pennazza, G., Santonico, M., Corsi, C., Roscioni, C., Paolesse, R., Natale, D. dan Amico, D 2008, A Preliminari Study on the Possibility to Diagnose Urinary Tract Cancers by an Electronic Nose, Sensors and Actuators B 131, 1-4

3. Charaklias, N., Raja, H., Humphreys, ML., Magan, N. dan Kendali, C.A., 2010, The Future of Early Disease Detection? Application of Electronic Nose Technology in Otolaryngology, The Journal of Laryngology \& Otology, 124, 823-827.

4. Dragonieri, S., Brinkman, P., Mouw, E., Zwinderman, A., Carratu, P., Resta, O., Sterk, P.J. dan Jonkers, R., 2013, An Electronic Nose Discriminates Exhaled Breath of Patients with Untreated Pulmonary Sarcoidosis from Controls, Respiratory Medicine 107, 1073-1078.

5. Dragonieri, S., Schee,M., Massaro, T., Schiavulli, N., Brinkman, P., Pinca. A., Caaratu, P., Spanevello, A., Resta, O., Musti, M. dan Sterk, P., 2012 An Electronic Nose Distinguishes Exhaled Breath of Patiens with Malignant Pleural Mesothelioma from Controls, Lung Cancer, 75, 326-331.

6. Jun, W, Gomez, A.H., Hu, G. dan Pereira, A.G., 2007, Discrimination of Storange shelf-life formandarin by E-Nose Technique, ScienceDirect, LWT 40, 681-689.

7. Peris, M. dan Gilabert, L.E., 2009, A 21 st Century Technique for Food Control: Electronic Noses, Analytica Chimica Acta 638, 1-15.

8. Tan dan Halim, A., 2012, Data Acquidition System Development of an Electronic Nose for Sulphate-reducing Bacteria Detection, International Conference on Intelligent and Advanced Systems.

9. Tian, X.Y., Cai, Q. dan Zhang, Y.M., 2012, Rapid Clasissification of Hairtail Fish and Pork Freshness Using an Electronic Nose Based on the PCA Method, Sensors, 260-277.

10. Turner, A.D.F. dan Magan, N., 2004, Electronic Nose and Disease Diagnosis, Microbiology, Volume 2, 161-165.

11. Zhang, M., Wang, X., Liu, Y., Xu, X. dan Zhou, G., 2012, Species Discrimination among Three Kinds of Puffer Fish Using an Electronic Nose Combined with Olfactory Sensory Evaluation, Sensor, Volume 12, 12562-12571. 